\title{
Sınıf Eğitimi Ana Bilim Dalı Öğrencileri için Barış Tutum Ölçeği Geliştirilmesi * $^{*}$
}

\author{
Developing a Peace Attitude Scale for the Primary Education \\ Department Students \\ Esin URLU**
}

• Geliş Tarihi: 19.07.2019 • Kabul Tarihi: 21.10.2019 • Çevrimiçi Yayın Tarihi: 21.10.2019

\section{$\ddot{O} \mathbf{z}$}

$\mathrm{Bu}$ çalışmanın amacı, sınıf eğitimi anabilim dalı öğrencilerinin barış tutum düzeylerinin anlaşılması için kullanılacak bir barış tutum ölçeği geliştirmektir. İlk olarak, ilgili araştırmalardan yola çıkılarak, barış tutumu bir çerçeve ile tanımlanmıştır. Daha sonra 81 öğretmen / öğretmen adayından barışa ilişkin duygu ve düşünceleri alınmıştır. Literatürdeki benzer ölçekler incelenerek, bu araştırmanın amacına uygun olan maddeler alınmıştır. Bu ölçeklerden alınan toplam 24 maddenin, barış tutumunun bazı boyutlarını karşıladığı ancak belirlenen alt boyutları karşılamada yetersiz olduğu görülmüştür. Eksik kalan alt boyutlar ile ilgili araştırmacı tarafindan 9 madde daha oluşturulmuştur. Maddeler için uzman görüşü alınarak ön uygulama için hazır hale getirilen ölçek, farklı üniversitelerde öğrenim gören sınıf eğitimi anabilim dalı öğrencilerine uygulanmıştır. Güvenilirlik analizi için Cronbach Alpha katsayısı hesaplanmış, geçerlik için açımlayıcı ve doğrulayıcı faktör analizleri uygulanmıştır. Analizler sonucunda 5 faktöre dağılmış 25 maddeden oluşan bir ölçek elde edilmiştir. Bu 5 faktör, ölçek varyansının \%47,02'sini açıklamaktadır. Ölçek için güvenirlik katsayısı Cronbach Alpha 0,89 olarak hesaplanmıştır. Ortaya çıkan barış tutumunun yapısının açıklanması ilgili literatür taramasıyla desteklenmiştir. Ölçeğin, benzer çalışmalara katkısının olacağı umulmaktadır. Anahtar sözcükler: barış, tutum, tutum ölçeği

Atıf:

Urlu, E. (2020). Sınıf eğitimi anabilim dalı öğrencileri için barış tutum ölçeği geliştirilmesi. Pamukkale Üniversitesi Eğitim Fakültesi Dergisi, 49, 331-352. doi: 10.9779/pauefd.593991

\footnotetext{
* Bu makale, Esin URLU'nun Prof. Dr. Ekber TOMUL danışmanlığında yürütülen "Sınıf eğitimi anabilim dalı öğrencilerinin barışa iliş̧in tutum ve görüşlerinin incelenmesi" konulu doktora tezinden yola çıkılarak hazırlanmıştır. Ayrıca bu makale oluşturulurken, VIII. Uluslararası Eğitimde Araştırmalar Kongresi'nde Esin URLU ve Ekber TOMUL tarafından sunulan "Barış tutum ölçeği geliştirilmesi" konulu özet bildiriden yararlanılmıştır.

**Arş. Gör. Dr., Manisa Celal Bayar Üniversitesi Eğitim Fakültesi Temel Eğitim Bölümü, esinizmir@gmail.com, https://orcid.org/ 0000-0003-3388-2399
} 


\begin{abstract}
The aim of the present study is to develop a peace attitude scale that will be used to understand the peace attitude levels of the primary education program students. Firstly, based on relevant research, the peace attitude was defined within a framework. Then, the feelings and thoughts of 81 teachers / primary education program students regarding peace were acquired. Similar scales in the literature were examined and items suitable for the purpose of the present study were abstracted from these scales. A total of 24 items from these scales were found to meet various dimensions of the peace attitude but were inadequate to meet the determined sub-dimensions. A further nine more items were created by the researcher related to the missing sub-dimensions. Expert opinion was taken for the scale, which was applied to primary education program students studying at various universities. Cronbach's alpha coefficient was calculated for reliability analysis and exploratory and confirmatory factor analyses were applied for validity. As a result, a scale consisting of five factors and 25 items was achieved. These 5 factors explain $47.02 \%$ of the variance of the scale. The reliability coefficient Cronbach Alpha for the scale was calculated as 0.89 . The explanation of the peace attitude with this structure was supported by the relevant literature review. It is expected that the scale will contribute to similar studies.
\end{abstract}

Keywords: peace, attitude, attitude scale

\title{
Cited:
}

Urlu, E.(2020). Developing a peace attitude scale of the primary education depertmant students. Pamukkale Üniversitesi Ë̆itim Fakültesi Dergisi, 49, 331-352. doi: 10.9779/pauefd.593991 


\section{Giriş}

İnsanlar topluluklar halinde yaşamaya başladıkları günden bu yana, yaşamlarını sürdürebilmek için hemen her dönemde birbirleriyle üstünlük yarışı içinde olmuşlardır. Kabileler, milletler veya devletler, anlaşmazlığa düştükleri bazı zamanlarda barış ile çözüm sağlayamamış - ya da denememiş - ve savaşmayı tercih etmişlerdir. Bu savaşlarda milyonlarca insan, ölümcül silahlar yüzünden can vermiş, milyonlarca insan göçlere maruz kalmıştır. Ayrıca sıcak savaşa maruz kalmış milyonlarca insan, savaşlar sebebiyle yaşamlarına engelli olarak devam etmektedirler (Purde, 2013). İnsanların savaşmayı tercih etmeleri ya da savaşmaya mecbur kalmaları yalnız üstünlük yarışından dolayı değildir. Machiavelli’ye göre, tarihe bakıldığında, insanın ihtiyaçları bitmediğinden, sürekli bir memnuniyetsizlik içerisindedir. Bu nedenle insan özünde kötü ve savaşçıdır (Tunçay, 2016). Tüm bu nedenlerden yola çıkılarak insanoğlunun var oluşundan bu yana sona ermeyen bir savaş sahası içinde yaşadığını söylemek yanlış olmaz. Savaşlar bu denli yaygın olduğundan, savaş karşısında barışın değerinin artması ve barış ile ilgili araştırmaların gün geçtikçe artması oldukça doğaldır. Toplum, barışa her geçen gün daha çok ihtiyaç duymaktadır.

Barış denildiğinde akla ilk gelen savaşsızlık halidir. Ancak bu ifade, barışın tanımlanması için yeterli değildir. Tıpkı sağlıklı olmanın, hastalık olmaması şeklinde ifade edilemeyeceği gibi, barış da yalnız savaşın olmaması olarak ifade edilemez (Galtung, 1985). Resmi kaynaklara bakıldığında Türk Dil Kurumunun (2016), barışı, uyum, karşılıklı anlayış ve hoşgörü ile oluşturulan ortam ve savaşın bittiğinin bir antlaşmayla belirtilmesinden sonraki durum olarak tanımladığı görülmektedir. UNESCO (2002) ise barışı, kadın - erkek eşitliği doğrultusunda cinsiyet ayrımının yapılmaması, bireylerin tercihleri doğrultusunda demokratik katılıma destek vermelerinin sağlanması, hoşgörü ve dayanışmayı temel alan, bireylerin kendilerini rahatça ifade edebildikleri ortamların oluşturulduğu, ekonomik ve sosyal gelişime verilen emeğin ve insan haklarına saygıya yönelik önemin arttırılması ile ilgili bir olgu olarak tanımlamıştır. Barışın farklı kaynaklar tarafından yapılan tanımlarının çoğunda hoşgörü vurgusunun yapıldığı görülmektedir. Öyleyse barışın, içinde karşılıklı hoşgörüyü barındıran, farklılıklara sayg1 gösterilen, çatışmayı değil, dayanışmayı ve insan haklarını temel alan bir süreç olduğu ifade edilebilir. Bundan yola çıkarak, araştırmacı tarafından, UNICEF'in barış eğitimi programında yer alan barışa ilişkin içeriklerden yararlanılarak, mevcut çalışma için oluşturulmuş barışın yapısı küpü Şekil 1'de sunulmuştur (Fountain, 1999). 

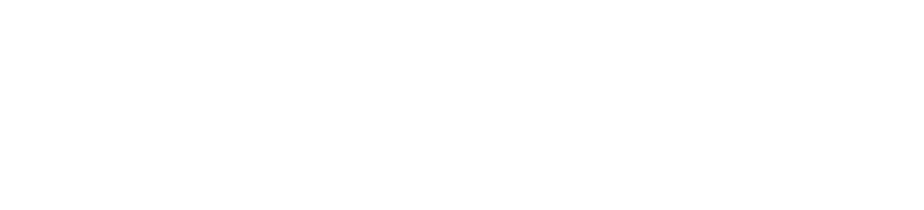

\section{Şekil 1. Barışın Yapısı}

Şekil 1'de görüldüğü gibi, barışın tam anlamıyla sağlanabilmesi için olmazsa olmaz üç değişken vardır. Bunlar çeşitlilik değişkenleri, insanlar hakları ve barışın düzeyleridir. Barış her düzeyde, insan haklarını temel alarak ve toplumdaki çeşitliliği destekleyecek şekilde sağlanmalıdır (Fountain, 1999). Bu üç değiş̧ken, barışın sağlanmasında önem konusunda denk ve iç içedirler. Sözgelimi, toplumsal barışın sağlanması için ortadan kaldırılması gereken unsurlar, toplumsal gruplar arasındaki önyargılar başta olmak üzere tüm çatışma yaratan nedenlerdir (Çoban, 2008). Bu nedenler incelendiğinde ise her düzeyde, insan hakları ve çeşitlilik değişkenlerine ilişkin deneyimlerle karşılaşılmaktadır (Allport, 1979). Diğer bir deyişle, barış yapısındaki değişkenler iç içe geçmiştir ve ilişkilidir. $\mathrm{Bu}$ nedenle, barışın yapısındaki bu iç içe geçmişliğin, barışın yeşertilmeye çalışıldığ tüm süreçlerde göz önünde bulundurulması gerektiği ifade edilebilir. Ayrıca Şekil 1'de sözü edilen değişkenlerden de bu aşamada söz etmekte yarar vardır.

Barışın, kişisel barış, kişiler arası barış, gruplar arası barış, ulusal barış ve uluslararası barış olmak üzere beş düzeyi bulunmaktadır (Fountain, 1999). Kişisel barış kavramı bazı kaynaklarda bireysel barış olarak da anılmaktadır ve bireyin iç huzuru ve kendi ile barışık olmasını konu edinir (Kerem ve Kamaraj, 2006; Kılcan, 2018). Kişiler arası barış, bireylerin gün içerisinde iletişim kurdukları kişilerle aralarındaki barış ve çatışmasızlığı ifade eder. Gruplar arası barış, toplumda yer alan farklı topluluklar arasındaki barış ile ilgilenir. Ulusal barış, ülkelerin, kendi içlerinde toplumsal barışın sağlanabilmesi için verdikleri hukuki çabayı, aldıkları karar ve kanunlar ile izledikleri politikaları konu alır. Uluslararası barış ise ülkelerin barışa yönelik dış politikalarını ve icraatlarını ele alır (Fountain, 1999). Karaman - Kepenekçi de (2010) yaptığı çalışmada, üniversite öğrencilerinin uluslararası barıştan, uluslararasındaki ilişkilerin iyileştirilmesini anladıklarını ortaya koymuştur. Bundan yola çıkılarak, barış deyince akla ilk gelen unsurlardan biri olan ülkeler arasındaki savaşların, barışın yalnız uluslararası barış düzeyi ile ilişkili olduğu ifade edilebilir.

Barış yapısındaki değişkenlerden bir diğeri ise insan haklarıdır. Aslında insan haklarını sınıflamak, insan haklarının ortaya çıkış sebebine terstir ve bu nedenle bu konu ile ilgilenen çoğu araştırmacı böyle bir sınıflamaya gitmemiştir. Ancak insan haklarının tarihsel gelişimine 
bakıldığında, insan haklarının ortaya çıkış şekillerine göre ister istemez birbirlerinden ayrıldığ görülmektedir (Özkan, 2015). Vasak (1977), bu hakları, farklı kuşaklarla tanımlamıştır. Birinci kuşak haklar, bireylerin zaten sahip oldukları, devletin fazladan müdahalede bulunmasına gerek olmayan, yalnız korumakla yükümlü olduğu hakları ifade eder. Yaşama hakkı, kişi dokunulmazlığı, kişi özgürlügü, kişi güvenliği, düşünce ve düşünceyi açıklama özgürlüğü, eşitlik hakkı ve seçme ve seçilme hakkı gibi bireysel özgürlükler, sivil ve siyasal haklar bu kuşağa dâhildir. Bu kuşaktaki haklar, temel haklar olarak görülmektedir. Ekonomik, sosyal ve kültürel haklar ise ikinci kuşak hakları oluşturmaktadır (Vasak, 1977). Bu haklar, 19. yüzyılda sanayi devrimi sonrası tartışılmaya başlanan haklardır. Çalışma hakkı, sosyal güvenlik hakkı, parasız eğitim ve öğrenim görme hakkı, sağlık hakkı ve kültürel yaşama katılabilme hakkı gibi haklar ikinci kuşak haklardandır. İkinci kuşak hakların elde edilebilmesi için devletin müdahalede bulunması gerekmektedir. Yani bu haklar, bireylerde hali hazırda bulunmamakta, devletin, ikinci kuşak hakları sağlayabilmek adına uygun zemini yaratabilmesi gerekmektedir.

Şekil 1'de dil, beceriler ve engeller, din, cinsel yönelim, cinsiyet, sosyal sınıf ve etnik kimlik çeşitlilik değişkenleri olarak ifade edilmiştir (Banks, 2013). Bu değişkenlerin etkisi toplumdan topluma değişebilir. Örneğin çok fazla savaş yaşamış ve uzun yıllar var olma mücadelesi göstermiş bir toplum için etnik kimlik diğer ülkelere göre çok daha önemli olabilir. Çünkü farklı etnik kimliğe sahip toplumlarla savaşa savaşa kendi etnik kimliklerine sıkıca bağlanmış ve diğer etnik kimlikli kişilere ayrımcı tutum gösteriyor olabilirler. Bu nedenle bu çeşitlilik değişkenleri yorumlanırken mevcut toplumun sosyolojik yapısı temel alınmalı ve ona göre değerlendirme yapılmalıdır. Ancak toplumdan topluma etkileri değişse de, temel noktalarıyla bir toplumda çeşitliliği sağlayan bileşenler bu değişkenlerdir. Bu bileşenler, çok kültürlü yapının çerçevesidir denilebilir. Bu kısmın başında denildiği gibi, bu üç değişken barışın yapısını oluşturur ve barışın sağlanması sürecinde birlikte ve iç içe rol alırlar. Bu noktada, barışın sağlanması sürecinde barış tutumunun geliştirilmesinden söz edilmesinde yarar vardir.

Barışın sağlanması için barış yapısındaki değişkenlerin göz önünde bulundurulması kadar, barış tutumunun anlaşılması ve geliştirilmesi de oldukça önemlidir. Tutum ise, çeşitli kavram ya da durumlara tepkide bulunma eğilimidir ve görüşe çok benzer. Ancak aralarında birkaç fark vardır. Bunlardan biri "farkında olma" durumudur. İnsanlar görüşlerinin farkındadırlar ancak tutumlarının farkında olmayabilirler (Tezbaşaran, 2008). Bu araştırmanın merkezinde yer alan barış kavramı, tüm dünyada en kolay kabul gören kavramlardan biridir. Ahlaki değerler açısından barışı reddetmek oldukça zordur (Bayraktar, 2012). Herhangi birine barış hakkında görüşleri sorulduğunda, savaş yanlısı görülme endişesi yaşayabileceğinden, olumsuz tutumunu belli etmesi ya da açığa çıkarması kolay olmamaktadır. Dolayısıyla barış tutumu hakkında fikir edinmek de oldukça güçtür. Doğru bir ölçme aracının kullanılmasının önemi, bu noktada yeniden hatırlanmaktadır. $\mathrm{Bu}$ nedenle, tutum ölçeği geliştirme çalışmalarında, süreç detaylı bir biçimde planlanmalıdır. Mevcut araştırmada da, geliştirilmesi planlanan ölçek için, diğer tüm detaylar gibi, hedef kitle de amaç doğrultusunda hassasiyetle belirlenmiştir. Sınıf eğitimi anabilim dalı öğrencileri için kullanılacak olan ölçme aracının geliştirilmesi sürecinde yalnız sınıf eğitimi anabilim dalı öğrencilerinden destek alınmış ve süreç boyunca - özellikle sınıf eğitiminde - barış ve barış tutumunun yeri üzerine tartışmalar yapılmıştır. Bu noktada bu tartışmalardan söz etmekte yarar vardır. 
Eğitim alanının önemli bir noktasında yer alan sınıf öğretmenliği, toplumda barışın gelişimi için oldukça önemli bir konumdadır. Çünkü barış yanlısı bir toplum için barış tutumu yüksek olan bireylere ihtiyaç duyulmaktadır. Barış tutumu yüksek olan bireyler ise barış tutumu yüksek çocukları yetiştirmekle mümkün olur. Çünkü John Locke'a göre insan zihni başlangıçta boş bir levhadır. İngiliz filozofların çoğu da zihinde başlangıçta hiçbir şey olmadığını ve insanın deneyimler yoluyla bilgi edindiklerini düşünmektedirler (Pakyürek, 2013). Dolayısıyla çocuklara nasıl bir eğitim verilirse çocukların zihinleri o yönde gelişecektir. Barış tutumu yüksek çocukların yetişebilmesi için ise sınıf öğretmenlerine büyük sorumluluk düşmektedir. Çocukların barışçıl bir şekilde eğitilmeleri, savaşların ve çatışmalarının zamanla azalması için adeta ön koşuldur. Örgün eğitim kurumların biri olan üniversitelerin misyonlarından biri bireylere meslek edindirmektir. Diğer bir deyişle geleceğin doktorları, mühendisleri, avukatları, öğretmenleri hali hazırda üniversiteler bünyesinde öğrenim görmektedirler. Bütün meslekler arasında öğretmenlik, insana en çok dokunan, insanla en çok iletişime geçen ve bir toplumun geleceğinin şekillenmesinde en önemli rolü oynayan mesleklerden biridir. Bunun yanı sıra atanan öğretmenler yurdun dört bir yanına dağılmaktadır. Dolayısıyla öğretmenlik mesleğinin, hizmet alanı genişliği bakımından en yaygın etki gücüne sahip mesleklerden biri olduğu söylenebilir. Tüm bu tartışmaların sonunda "Barış eğitimini verecek, geleceğin öğretmenlerinin barışa ilişkin tutumları nasıldır?" sorusu karşımıza çıkmaktadır. Bu sorunun karşımıza çıkmasının en önemli nedeni, karakter eğitiminin en önemli kısmı olan barış gibi değerlerin, öğretmeden öte, model olma ile kazandırılabileceği gerçeğidir (Kartal, 2018; Obidike, Bosah ve Olibie, 2015). Dolayısıyla bu araştırmada, sınıf eğitimi anabilim dalı öğrencilerinin barış tutum düzeylerinin anlaşılması için kullanılacak bir barış tutum ölçeği geliştirmek amaçlanmıştır. Veri toplanırken tüm bölgelere ulaşılamaması araştırmanın sınırlı̆̆ıdır.

\section{Barış Tutum Ölçeği Geliştirilmesi Süreci}

Barış tutum ölçeği geliştirilirken izlenen adımlar Şekil 2'de sunulmuştur. Şekil 2'de de görüldüğü gibi, barış tutum ölçeği geliştirilirken, ilk olarak eğitim fakültesi öğrencilerinin ve sınıf ögretmenlerinin barış ile ilgili duygu ve düşünceleri alınmıştır. Bu aşamada 61'i yüz yüze, 20'si elektronik ortamda olmak üzere 81 öğretmen / öğretmen adayına ulaşılmış ve barış ile ilgili düşüncelerini yazılı olarak ifade etmeleri istenmiştir. Görüşler alınırken ilk olarak "Barış ile ilgili duygu ve düşünceleriniz nelerdir?" sorusu sorulmuş, ilk aşamada aklına bir ifade gelmeyen katılımcılara "Barış deyince aklınıza neler geliyor?" sorusu sorularak düşüncelerinin ortaya çıkması konusunda yardımcı olunmuştur. Sonra alınan ifadelerin anlaşılabilirliği, Türkçe eğitimi bölümünde görevli bir öğretim elemanından destek alınarak incelenmiştir. Daha sonra, UNICEF'in barış eğitimi programında belirtilen barışın düzeyleri esas alınarak bir çerçeve oluşturulmuştur. Bu düzeyler, kişisel barış, kişiler arası barış, gruplar arası barış, ulusal barış ve uluslararası barış olarak ifade edilebilir. 


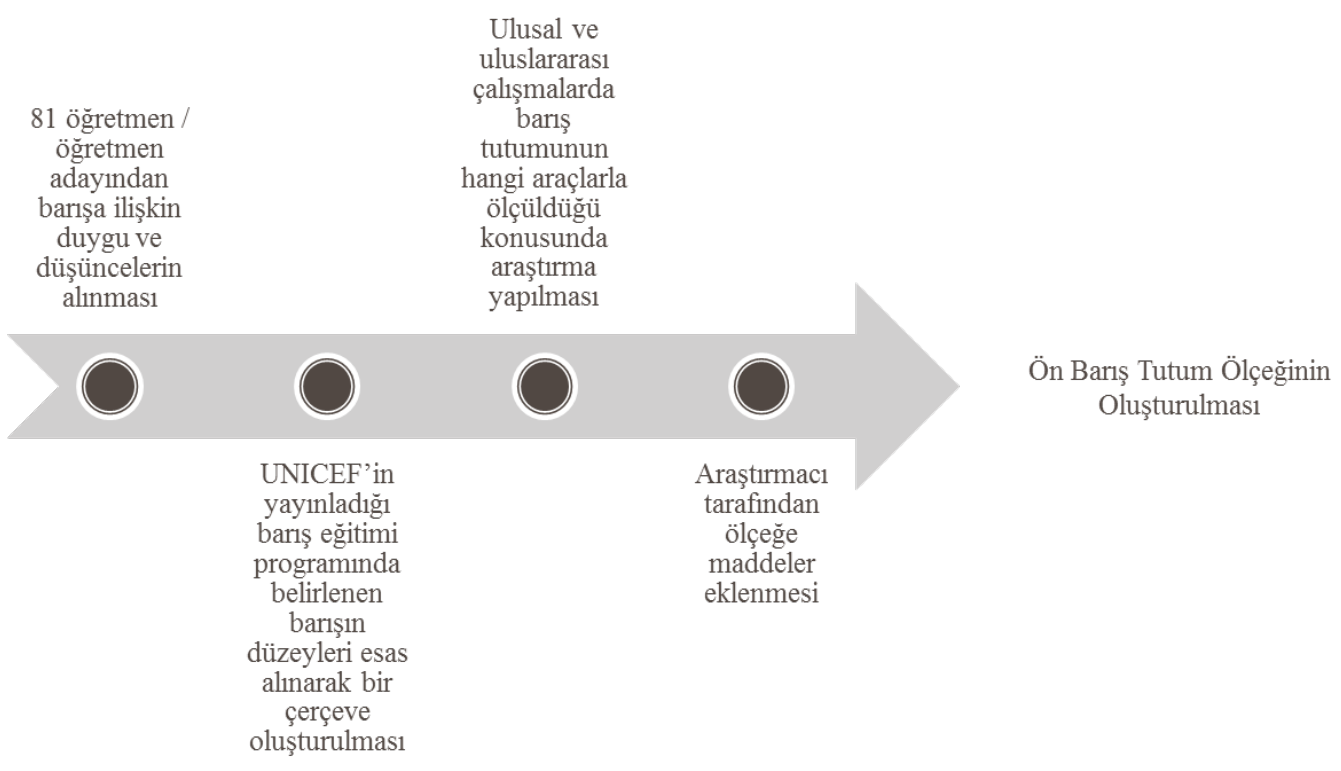

\section{Şekil 2. Ön barış tutum ölçeği geliştirme süreci}

Barış tutum ölçeği maddelerinin oluşturulabilmesi için ulusal ve uluslararası araştırmalarda barış tutumunun hangi araçlarla ölçüldüğü konusunda bir araştırma yapilmıştır. Yurtdışında yapılan araştırmalar incelendiğinde, zihinsel barış ölçeğine ulaşılmıştır (Lee, Lin, Huang ve Fredrickson, 2013). Bu ölçekte yalnız kişisel barış boyutu ele alınmıştır ve ölçeğin kapsamında kişisel mutluluk ve mutlu olabilme kavramları yer aldığından bu araştırma için uygun bir referans olarak görülmemiştir. Daha sonra bu konuda yurtiçinde nasıl ölçekler geliştirildiği araştırılmıştır. Yurtiçinde yapılmış çalışmalara bakıldığında, Aktaş'ın (2012) kendi geliştirdiği savaş ve barış ölçeği ile ve Eryılmaz'ın (2014) geliştirdiği barışa yönelik tutumlar ölçeği ile karşılaşılmaktadır. Eryılmaz'ın geliştirdiği ölçek beş maddeden oluşan ve kişisel ve kişiler arası düzeyde barışı ölçen bir ölçektir. Aktaş'ın ölçeği incelendiği ise, ölçeğin ortaöğretim öğrencileri için geliştirmesi sebebiyle, bu çalışma için, hedef kitle açısından uygun bir ölçek olmadığı kanaatine varılmıştır. Aynı zamanda barışın yanı sıra savaşa yönelik tutumları da ölçme amacı taşıdığından - her ne kadar savaş, barışa uzak bir konu olmasa da ölçeklerin boyutları farklılaştığından - Aktaş'ın ölçeğinin ancak çok az bir kısmı geliştirilmesi planlanan barış tutum ölçeği ile örtüşmektedir. Bu nedenle bu örtüşen az alan ve konu ortaklığı sebebiyle bu ölçek, barışın boyutları da göz önünde bulundurularak incelenmiştir. İnceleme sonucunda bazı maddelerin çeşitli düzenlemelerle, geliştirilecek barış tutum ölçeğinde kullanılabileceği düşünülmüştür. Bunu yanı sıra, doğrudan barışa yönelik tutumu ölçen Türkçe bir çalışma bulunmaması nedeniyle barış kapsamında yer alan çeşitlilik değişkenleri ve insan hakları kavramlarından yola çıkılarak, bu kavramlara ilişkin tutumları ölçen Türkçe bir ölçek geliştirilip geliştirilmediği araştırılmıştır. Çeşitlilik değişkenleri alt boyutu ile ilişkili olarak Çalışkan ve Sağlam'ın geliştirdiği “Hoşgörü Eğilim Ölçeği” (2012), Ayaz'ın geliştirdiği “Çokkültürlülük Alg1 Ölçeği” (2016), Polat'ın, Munroe ve Pearson'ın (2006) aynı isimli ölçeğinden yola çıkarak geliştirdiği "Çokkültürlülük Tutum Ölçeği” (2012) ve Damgacı ve Aydın'ın geliştirdiği “Çokkültürlü Eğitim Tutum Ölçeği” (2013) ile karşılaşılmıştır. Bu dört ölçekteki maddeler incelenmiş ve bazı maddelerin, öğretmen / öğretmen adaylarından alınan duygu ve düşüncelere de bakılarak, yeniden düzenlenebileceği ve bu çalışmada geliştirilen barış tutum ölçeğinde kullanılabileceği düşünülmüştür. Geliştirilmiş olan tüm bu ölçeklerden seçilen 
tüm maddeler, 81 öğretmen / öğretmen adayından alınan duygu ve düşünceler dikkate alınarak revize edilmiştir ve oluşturulan maddeler madde havuzuna eklenmiştir. Bu kısımda sözü edilen ölçeklerden alınan maddelerin, barış tutumunun bazı boyutlarını karşıladığı ancak belirlenen tüm boyut ve alt boyutları karşılamada yetersiz olduğu görülmektedir. Bu nedenle, eksik olan bu alt boyutlarla ilgili UNICEF'in yaptığı çalışmalara yeniden bakılmış (Fountain, 1999) ve barış tutumunun bu boyutları ile ilgili vurgulanan noktalar incelenmiştir. Bu inceleme sonucunda ve literatürde yapılmış diğer çalışmalar ve öğretmen / öğretmen adaylarından alınan ifadeler de göz önünde bulundurularak eksik kalan bu alt boyutlar ile ilgili olarak araştırmacılar tarafından da maddeler eklenmiştir.

Barış tutum ölçeği için barışın belirlenen boyutlarından ve konu ile ilgili önceden yapılmış araştırmalardan yola çıkılarak toplam 33 maddelik madde havuzu oluşturulmuştur. Maddeler oluşturulduktan sonra üzerinde düzeltilmeler yapılmış, olgusal ifadeler çıkarılmış, tutumu ölçmeye yönelik ifadeler yazılmaya çalışılmıştır. Maddeler araştırmacı tarafından düzenlendikten sonra dil açısından Türkçe Eğitimi bölümünde görev yapan bir öğretim elemanı tarafindan kontrolleri yapılmıştır. Daha sonra benzer konularda çalışmalar yapmış ikisi psikolojik danışmanlık ve rehberlik anabilim dalında, biri eğitim yönetimi ve politikası bölümünde, diğeri ise sınıf eğitimi anabilim dalında görev yapan toplam dört öğretim üyesinden görüşler alınmış ve görüşler doğrultusunda düzenlemeler yapılmıştır. Maddeler oluşturulduktan sonra defalarca okunmuş, olgusal ifadeler çıkarılmış, tutumu ölçmeye yönelik ifadeler yazılmaya çalışılmıştır. Tezbaşaran'ın (2008) dediği gibi, aşırı olumlu / olumsuz uçtaki ifadeler, bireylerin tepkilerinin ortaya doğru çekilmesine ve aşırı uçlardan kaçınma eğilimine sebep olabilir. $\mathrm{Bu}$ nedenle, maddeler mümkün olduğunca sadeleştirilmiş ve maddelerin mümkün olduğunca 1lımlı ifadelerden oluşması sağlanmıştır.

\section{Yöntem}

Araştırma, bir ölçek geliştirme çalışması olduğundan, temel araştırma niteliğindedir. Araştırma sorusu: "Eğitim fakültesi sınıf eğitimi programı ögrencilerinin barışa yönelik tutumları nasıl bir ölçme aracı ile ölçülebilir?” sorusudur.

\section{Çalışma Grubu}

33 maddeden oluşan ön uygulama ölçeği oluşturulduktan sonra, açımlayıcı faktör analizi ve güvenirlik analizi yapılabilmesi için 335 eğitim fakültesi sınıf eğitimi programı öğrencisine ulaşılarak ölçek uygulanmıştır. Ölçek, Manisa Celal Bayar Üniversitesi’nde öğrenim görmekte katılımcılara, 2017 - 2018 akademik yılı bahar döneminde uygulanmıştır. Bu aşamada Manisa

Celal Bayar Üniversitesi seçilirken, araştırmacının ulaşım kolaylığı göz önünde bulundurulmuştur.

Açımlayıcı faktör analizi ve güvenirlik analizi işlemleri ardından, toplam dokuz üniversitede öğrenim gören 1237 öğrenciden veri toplanarak doğrulayıcı faktör analizi işlemi uygulanmıştır. Bu katılımcı grubu, aynı zamanda mevcut araştırmanın da yapıldığı doktora tezi sürecinde işbirliği yapılan öğrencilerdir. Sözü edilen 1237 öğrenciden veri toplama işlemi, 2017 - 2018 akademik yılı bahar dönemi ve 2018 - 2019 akademik y1lı güz döneminde tamamlanmıştır. Bu araştırmada her bölgeden en az bir eğitim fakültesi seçilmeye çalışılmıştır. $\mathrm{Bu}$ işlemin amac1, mümkün olduğunca çok bölgede öğrenim gören öğrencilere ulaşılması ve bununla birlikte araştırmanın hata payının mümkün olduğunca düşürülebilmesidir. Bu süreçte 
bazı üniversitelerin gerekli izinleri vermemesi sebebiyle ancak beş bölgeye ulaşılabilmiş ve bu beş bölgedeki toplam dokuz üniversiteden veri toplanmıştır. Çalışma grubu ile ilgili detaylı bilgi Tablo 1'de verilmiştir.

Tablo 1. Doğrulayıcı Faktör Analizi için Çalışma Grubu Detayı

\begin{tabular}{lllll}
\hline & Üniversite & Bölge & N & $\%$ \\
\hline 1 & Manisa Celal Bayar Üniversitesi & Ege Bölgesi & 71 & 6 \\
2 & Sinop Üniversitesi & Karadeniz Bölgesi & 188 & 15 \\
3 & Burdur Mehmet Akif Ersoy Üniversitesi & Akdeniz Bölgesi & 153 & 12 \\
4 & Ağrı İbrahim Çeçen Üniversitesi & Doğu Anadolu Bölgesi & 119 & 10 \\
5 & Isparta Süleyman Demirel Üniversitesi & Akdeniz Bölgesi & 122 & 10 \\
6 & Başkent Üniversitesi & İç Anadolu Bölgesi & 185 & 15 \\
7 & Dokuz Eylül Üniversitesi & Ege Bölgesi & 173 & 14 \\
8 & Adnan Menderes Üniversitesi & Ege Bölgesi & 113 & 9 \\
9 & Ahi Evran Üniversitesi & İç Anadolu Bölgesi & 113 & 9 \\
\hline & Toplam & & 1237 & 100 \\
\hline
\end{tabular}

Tablo 1 incelendiğinde toplam 1237 sinıf eğitimi programı öğrencisinin \%5,7’sinin Manisa Celal Bayar Üniversitesi, \%15,2'sinin Sinop Üniversitesi, \%12,4'ünün Burdur Mehmet Akif Ersoy Üniversitesi, \%9,6'sının Ağrı İbrahim Çeçen Üniversitesi, \%9,9'unun Isparta Süleyman Demirel Üniversitesi, \%15'inin Başkent Üniversitesi, \%14'ünün Dokuz Eylül Üniversitesi, \%9,1'inin Adnan Menderes Üniversitesi ve \%9,1'inin Ahi Evran Üniversitesi öğrencisi olduğu görülmektedir. Doğrulayıcı faktör analizi için Manisa Celal Bayar Üniversitesi'nde veri toplanırken, araştırmaya katılan katılımcıların, daha önce açımlayıcı faktör analizi için veri toplanırken çalışma grubunda bulunmamış olmalarına dikkat edilmiştir.

Çalışma grubundaki katılımcı sayısı için farklı araştırmacılar farklı görüşler sunmuşlardır. Nunally (1978) ölçek geliştirme çalışmalarında çalışma grubundaki katılımcı sayısı için madde sayısının on katını önerirken, Tabachnick ve Fidell (2001) en az 300 katılımcı sayısını önermiştir (akt. Field, 2009). Bu görüşlerden yola çıkılarak, bu araştırmada iki ayrı analize giren (açımlayıcı ve doğrulayıcı faktör analizi) çalışma grubundaki katılımcı sayısının 335 ve 1237 olmasının faktör analizi için yeterli olduğu söylenebilir. Çalışma grubundaki katılımcı sayısının yeterli olup olmadığına dair bir başka ölçüt ise Kaiser - Meyer - Olkin (KMO) örneklem yeterliliği testidir. Bu teste ilişkin veriler ise bulgular kısmında sunulmuştur.

\section{Verilerin Toplanması ve Analizi}

Ön uygulama için hazır hale getirilen ölçeğin uygulanabilmesi için etik kurul raporu ve izin belgesi alınmıştır. Araştırmacı verilerin toplandığı dokuz üniversitenin dördüne bizzat gitmiş, beş üniversitede ise bazı öğretim elemanları ile işbirliği yapılmıştır. Araştırmacı kendi gittiği üniversitelerde de ön uygulama için bazı öğretim elemanları ile işbirliği yapmıştır. İşbirliği yapılan öğretim elemanlarının, belirlenen derslerinin ilk on beş dakikasına, araştırmacı girmiştir. Derse giren araştırmacı ilk olarak kendini tanıtmış ve öğrencilerin kendilerini rahat hissetmeleri için her grup için yaklaşık beş dakika süren kısa sohbetler etmiştir. Ardından öğrencileri araştırma hakkında bilgilendirmiştir. Daha sonra, gönüllülük esasını da vurgulayarak öğrencilerden veri toplamıştır. Bu ön uygulama sonucunda - nicel verilerle çalışıldığı için istatistik paket programından yararlanılarak ölçeğin güvenirlik analizi, Cronbach Alpha iç tutarlılık katsayısı ile ölçülmüştür. Ölçeğin yapı geçerliği ise ilk olarak 335 katılımcıdan 
toplanan verilerden yararlanılarak açımlayıcı faktör analizi ile incelenmiştir. Daha sonra, 1237 ayrı katılımcıdan toplanan veriler üzerinde doğrulayıcı faktör analizi işlemi gerçekleştirilmiştir.

\section{Bulgular}

Barış tutum ölçeği ön uygulaması için hazırlanan ölçek, katılımcılara uygulandıktan sonra, veriler istatistik paket programına tek tek girilmiş ve kontrol edilmiştir.

Ölçeğin yapı geçerliği faktör analizi ile kontrol edilebilir (Fraenkel ve Wallen, 2009). Bu nedenle, yapı geçerliğinin sağlanabilmesi için 33 madde ile faktör analizi yapılmıştır. Faktör analizi, aynı yapıyı ölçen değişkenleri bir araya getirmeyi amaçlayan bir işlemdir. Keşfedici faktör analizi ve doğrulayıcı faktör analizi olmak üzere iki tür yaklaşıma sahiptir. Keşfedici faktör analizi, değişkenler arası ilişkilerden faktör bulmayı sağlarken, doğrulayıcı faktör analizi ise daha çok, var olan bir kuramın test edilmesinde kullanılır (Büyüköztürk, 2012, s. 123). Bu araştırmada yeni bir ölçek geliştirilmeye çalışıldığından ve herhangi bir kurama bağlı olmadan, araştırmacı tarafından oluşturulmaya çalışılan yeni bir yapı söz konusu olduğundan, ilk olarak keşfedici faktör analizi kullanılmıştır. Olumsuz maddeler ters olmak üzere, istatistik programına tek tek girilen veriler üzerinde uygulanan faktör analizi sonucunda elde edilen KMO ve Barlett Testi sonuçları Tablo 2'de verilmiştir.

\section{Tablo 2. KMO ve Bartlett Testi Sonuçları}

\begin{tabular}{llll}
\hline & sd & KMO & p \\
\hline Barış Tutum Ölçeği & 300 &, 89 &, 00 \\
\hline
\end{tabular}

Tablo 2'ye göre Kaiser - Meyer Olkin (KMO) değeri $\mathrm{p}<0,01$ anlamlılık düzeyinde 0,89 olarak elde edilmiştir. KMO değeri 0,5 - 0,7 arasında orta, 0,7 - 0,8 arasında iyi, 0,8 - 0,9 arasında çok iyi ve 0,9 üzerinde muhteşem şekilde faktör analizine uygunluğu göstermektedir (Hutcheson ve Sofroniou, 1999; akt. Field, 2009, s. 659). Buna göre, bu araştırma için elde edilen KMO değeri, faktör analizi yapmaya çok iyi derecede ve anlamlı düzeyde uygundur.

Faktör analizinde üç temel yöntem vardır. Bunlar temel bileşenler analizi (principal components), temel eksen faktör analizi (principal axis factoring) ve maksimum olabilirlik analizidir (maximum likelihood) (Park, Dailey ve Lemus, 2002). Birçok çalışmada faktör analizi yapıldığı düşünülerek temel bileşenler analizi yapılmaktadır. Ancak temel bileşenler analizi, içerdiği işlemler bakımından faktör analizinden ayrılmaktadır (Zöller, 2012). Temel bileşenler analizi, ölçümün hatasız olduğunu varsaymaktadır, dolayısıyla içinde hata varyansını da barındırmaktadır (Park vd., 2002). Bu çalışmada ölçüm hatası ortadan kaldırılarak analiz yapılmak istendiği için faktör analizi yöntemi olarak temel eksen faktör analizi yöntemi tercih edilmiştir.

Faktör analizi yapmadan faktör sayısını belirlemek ve isimlendirmek zor olsa da, araştırmacı elde etmeyi beklediği faktör sayısını ve doğasını tahmin etmeli ve değişken seçiminde bunu kılavuz olarak kullanmalıdır (Fabrigar, Wegener, MacCallum ve Strahan, 1999). Faktör sayıs1 belirlenirken geleneksel bir yöntem olan yamaç birikinti grafiği kullanılabilir. Ayrıca buna ek olarak, teorik olarak en mantıklı ve en kolay yorumlanabilen modelin belirlenmesi de faktör sayısı belirlenirken dikkate alınmalıdır (Fabrigar vd., 1999). 
Kaiser'e göre (1960) özdeğeri 1'den büyük olan tüm faktörler toplam varyansa önemli katk1 yapmaktadır ve faktör olarak alınmalıdır (akt. Field, 2009). Bu çalışmada da tüm bu unsurlar göz önünde bulundurularak, hem barış tutumunun yapısı göz önünde bulundurulmuş, hem de yamaç birikinti grafiğinden faydalanılmıştır. Barış tutum ölçeği için beklenen beş faktör, barışın düzeyleridir (kişisel barış, kişiler arası barış, gruplar arası barış, ulusal barış ve uluslararası barış). Dolayısıyla ilk olarak analizden beş faktörlü bir yapı beklenmiştir. Şekil 3'te mevcut çalışmaya ilişkin yamaç birikinti grafiği sunulmaktadır.

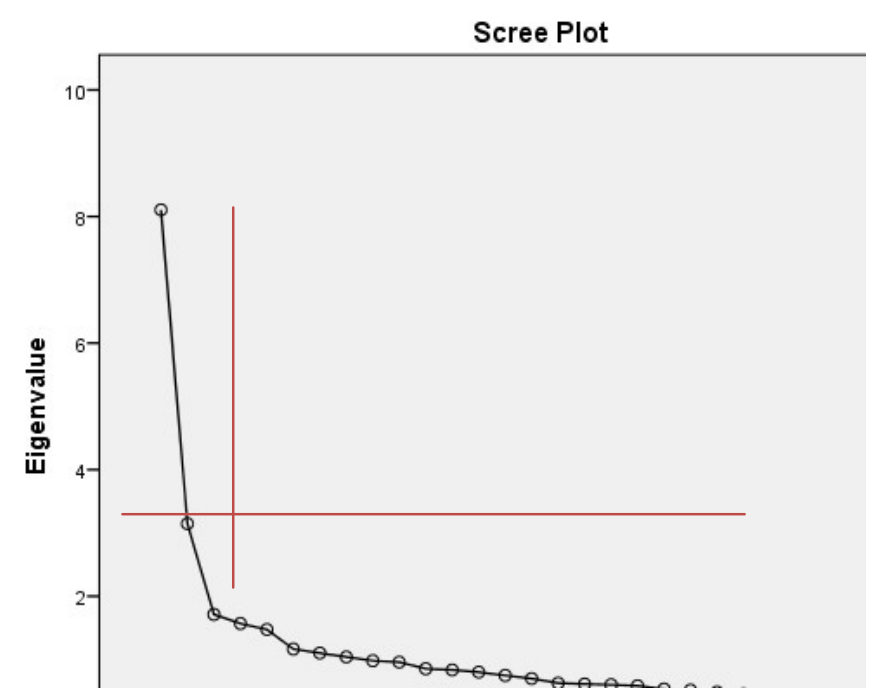

\section{Şekil 3. Barış tutum ölçeği yamaç birikinti grafiği}

Şekil 3'teki barış tutum ölçeğine ait yamaç birikinti grafiğine bakıldığında, dikey eksende özdeğerlerin, yatay eksende ise faktörlerin yer aldığı görülmektedir. Grafiğe göre, özellikle 5 . faktörden sonra grafiğin düzleşmeye başlaması, ölçeğin beş faktörlü olacağı tahmininin oluşmasina neden olmuştur.

Verilerin daha rahat yorumlanabilmesi için faktör analizi sırasında uygulanabilecek iki tür döndürme işlemi vardır. Bu döndürme şekilleri dik (ortogonal) ve eğik (oblik) döndürmedir. Eğer faktörler arasında korelasyon öngörülüyorsa eğik döndürme, yoksa dik döndürme yöntemi kullanılır (Field, 2009). Araştırmacılar kimi zaman faktörleri arasında korelasyon olup olmadığ konusunda kararsızlığa düşmekte ve doğrudan, dik döndürmeler arasında en popüler döndürme olan varimax döndürme metodunu tercih etmektedirler. Aslında bunun yerine, Fabrigar vd. önerisi, araştırmacıları ilk olarak eğik döndürme yapmaları, eğer bu metotta faktörler mantıklı bir şekilde çözüme ulaşmazsa - zaten aralarında korelasyon olmadığı anlaşılacağından - daha sonra dik döndürme yapmalarıdır (1999). Bu çalışmada çıkması öngörülen faktörler ele alındığında, faktörler arasında korelasyon çıkabileceği düşünülmüştür. Bu nedenle, bu çalışmada faktörler arasında korelasyon oluşabileceğinden, ilk olarak eğik döndürme metotlarından direct oblimin döndürme metodu kullanılmıştır. Ancak bu metotta faktörler literatüre uyumlu şekilde dağılım göstermediğinden, daha sonra varimax döndürme metodu ile analiz gerçekleştirilmiştir.

Açımlayıcı faktör analizi işlemi sonucunda madde faktör yükü 0.30 'dan düşük olan 8 madde ölçekten çıkarılmıştır. Çünkü maddenin faktörde doğru temsile sahip olabilmesi için faktör yükünün 0,3 ve üzerinde olması beklenir (Büyüköztürk, 2012). Kalan 25 madde üzerinde 
yeniden faktör analizi yapılmıştır. Faktör analizi sonuçlarına göre, ölçek, özdeğeri 1'in üzerinde olan 5 faktör altında toplanmıştır. Ayrıca bu analiz sonucunda, maddeler arasında binişiklik oluşmamıştır. Tablo 3 'te 25 maddeden oluşan barış tutum ölçeğinin maddelerine ilişkin yapılan faktör ve madde analizi sonuçları yer almaktadır.

\section{Tablo 3. Barıș Tutum Ölçeği Madde ve Faktör Analizi Sonuçları}

Döndürülmüş Faktör Yük Değerleri

\begin{tabular}{|c|c|c|c|c|c|c|}
\hline \multirow{2}{*}{$\begin{array}{l}0 \\
z \\
0 \\
\frac{0}{0} \\
\sum^{\pi}\end{array}$} & \multirow{2}{*}{$\begin{array}{l}0 \\
z \\
0 \\
\frac{0}{0} \\
\sum_{0}^{\pi} \\
i \\
\bar{D}\end{array}$} & \multirow[b]{2}{*}{$\begin{array}{l}\text { Faktör 1: } \\
\text { Toplumsal } \\
\text { Barış }\end{array}$} & \multirow{2}{*}{$\begin{array}{l} \\
\text { Faktör 2: } \\
\text { Barışa önem } \\
\text { verme }\end{array}$} & \multirow{2}{*}{$\begin{array}{l} \\
\text { Faktör 3: } \\
\text { Kişisel ve } \\
\text { kişiler arası } \\
\text { barış }\end{array}$} & \multirow{2}{*}{$\begin{array}{l} \\
\text { Faktör 4: } \\
\text { Savaşın } \\
\text { karşısında barış }\end{array}$} & \multirow{2}{*}{$\begin{array}{l} \\
\text { Faktör 5: } \\
\text { Farklılıklara açık } \\
\text { olma }\end{array}$} \\
\hline & & & & & & \\
\hline 19 & 1 & ,644 & & & & \\
\hline 22 & 2 &, 603 & & & & \\
\hline 33 & 3 & ,602 & & & & \\
\hline 17 & 4 & ,589 & & & & \\
\hline 28 & 5 & ,589 & & & & \\
\hline 21 & 6 &, 584 & & & & \\
\hline 15 & 7 &, 560 & & & & \\
\hline 27 & 8 &, 533 & & & & \\
\hline 8 & 9 &, 518 & & & & \\
\hline 11 & 10 &, 518 & & & & \\
\hline 12 & 11 & ,496 & & & & \\
\hline 2 & 12 & ,407 & & & & \\
\hline 24 & 13 & & ,743 & & & \\
\hline 25 & 14 & &, 711 & & & \\
\hline 26 & 15 & & ,477 & & & \\
\hline 32 & 16 & & ,465 & & & \\
\hline 7 & 17 & & & ,766 & & \\
\hline 6 & 18 & & & ,681 & & \\
\hline 3 & 19 & & & ,406 & & \\
\hline 29 & 20 & & & & ,808 & \\
\hline 30 & 21 & & & &, 736 & \\
\hline 31 & 22 & & & &, 501 & \\
\hline 16 & 23 & & & & & ,752 \\
\hline 13 & 24 & & & & &, 541 \\
\hline 18 & 25 & & & & &, 502 \\
\hline \multicolumn{2}{|c|}{ Özdeğerler } & 4,164 & 2,271 & 1,825 & 1,814 & 1,681 \\
\hline \multicolumn{2}{|c|}{$\begin{array}{l}\text { Açıklanan } \\
\text { Varyans Oran }\end{array}$} & 16,655 & 9,083 & 7,301 & 7,256 & 6,724 \\
\hline \multicolumn{2}{|c|}{$\begin{array}{l}\text { Faktör } \\
\text { Cronbach } \\
\text { Alpha } \\
\end{array}$} & 0,87 & 0,72 & 0,70 & 0,78 & 0,66 \\
\hline \multicolumn{3}{|c|}{$\begin{array}{l}\text { Açıklanan Toplam Varyans } \\
\text { Oranı }\end{array}$} & 47,02 & & & \\
\hline \multicolumn{3}{|c|}{ BTÖ Cronbach Alpha } & 0,89 & & & \\
\hline
\end{tabular}


Tablo 3 incelendiğinde ölçeğin toplam 5 faktöre dağılmış 25 maddeden oluştuğu görülmektedir. İlk faktör, ölçeğe ilişkin toplam varyansın \%16,66'sını, ikinci faktör, \%9,08, üçüncü faktör $\% 7,30$, dördüncü faktör $\% 7,26$ ve beşinci faktör $\% 6,72$ 'sini açıklamaktadır. Bu 5 faktör, ölçek varyansının \%47,02'sini açıklamaktadır. Çok faktörlü ölçeklerde açıklanan varyansın \%40 üzerinde olması yeterli görülmektedir (Çokluk, Şekercioğlu, ve Büyüköztürk, 2012). Zaten sosyal bilimlerde açılanan toplam varyansın çok yüksek değerler alması zor olduğundan, geçerliği iyi bir ölçekte açılanan toplam varyansın $\% 40$ ve üzeri olmas1 beklenmektedir (Tavşancıl, 2002).

Faktör döndürme sonrasında, ölçeğin birinci faktörünün on iki maddeden $(2,8,11,12$, $15,17,19,21,22,27,28$ ve 33), ikinci faktörün dört maddeden $(24,25,26$ ve 32), üçüncü faktörün üç maddeden ( 3,6 ve 7$)$, dördüncü faktörün üç maddeden $(29,30,31)$ ve beşinci faktörün üç maddeden (13, 16 ve 18) oluştuğu belirlenmiştir. Birinci faktörde yer alan maddelerin faktör yük değerleri 0,407 - 0,644 arasında, ikinci faktörde yer alan maddelerin faktör yük değerleri 0,465 - 0,743 arasında, üçüncü faktörde yer alan maddelerin faktör yük değerleri 0,406 - 0,766 arasında, dördüncü faktörde yer alan maddelerin faktör yük değerleri $0,501-0,808$ arasında ve beşinci faktörde yer alan maddelerin faktör yük değerleri $0,502-$ 0,752 arasında değişmektedir. Faktörlere, maddelerin içerikleri dikkate alınarak isim verilmeye çalış1lmıştır. İlk faktör toplumsal barış, ikinci faktör barışa önem verme, üçüncü faktör kişisel ve kişiler arası barış, dördüncü faktör savaşın karşısında barış ve beşinci faktör farklılıklara açık olma olarak isimlendirilmiştir. Ölçek geliştirilirken barışın düzeylerinin (kişisel, kişiler arası, gruplar arası, ulusal ve uluslararası) faktörleri belirleyeceği düşünülmüştür. Ancak yapılan analizler sonucunda ortaya çıkan faktörlere bakıldığında, ortaya çıkan bu yapının, bu araştırmanın temel kaynaklarından olan UNICEF'in barış tutumu içeriği ile daha iyi örtüştüğü görülmüştür.

Tüm ölçek için güvenirlik katsayısı Cronbach Alpha 0,89 olarak hesaplanmıştır. 0,70 üzeri güvenirlik katsayısı, sosyal bilimler için yeterli görülmektedir (Field, 2009). Bu bilgiye dayanarak, ölçeğin güvenirliğinin oldukça yüksek olduğu söylenebilir. Tablo 4'te ölçeğin son hali, faktörleri ile sunulmuştur.

Tablo 4. Faktörleri ile Barış Tutum Ölçeği

\begin{tabular}{|c|c|c|c|c|c|}
\hline FAKTÖR & $\begin{array}{l}\text { Yeni } \\
\text { Madde } \\
\text { No }\end{array}$ & $\begin{array}{l}\text { Madde } \\
\text { No }\end{array}$ & $\begin{array}{l}\text { Madde } \\
\text { Türü }\end{array}$ & $\begin{array}{l}\text { Düzeltilmiş Madde } \\
-\quad r \quad \text { Toplam } \\
\text { Korelasyonu }\end{array}$ & Madde \\
\hline \multirow{5}{*}{$\begin{array}{l}\text { Toplumsal } \\
\text { Barış }\end{array}$} & 1 & 19 & + &, 583 & $\begin{array}{l}\text { Birden fazla kültürün eşit } \\
\text { haklara } \\
\text { topluluklarda yah yşamayı tercih } \\
\text { ederim. }\end{array}$ \\
\hline & 2 & 22 & + & ,643 & $\begin{array}{l}\text { Eğitim sistemleri firsat eşitliği } \\
\text { sağlayacak } \\
\text { düzekilde } \\
\text { şlenmelidir. }\end{array}$ \\
\hline & 3 & 33 & + &, 528 & $\begin{array}{l}\text { Barışın manevi değerleri } \\
\text { güçlendirdiğini düşünüyorum. }\end{array}$ \\
\hline & 4 & 17 & + & ,630 & $\begin{array}{l}\text { Farklı kültürlerin bir arada } \\
\text { yaşaması zenginliktir. }\end{array}$ \\
\hline & 5 & 28 & + &, 550 & $\begin{array}{l}\text { Ülkelerin öncelikleri arasında } \\
\text { barışın sağlanması olmalıdır. }\end{array}$ \\
\hline
\end{tabular}




\begin{tabular}{|c|c|c|c|c|c|}
\hline & 6 & 21 & + & ,443 & $\begin{array}{l}\text { Ülkelerin eğitim politikası, } \\
\text { kültürel çeşitliliği kapsamalıdır. }\end{array}$ \\
\hline & 7 & 15 & + &, 533 & $\begin{array}{l}\text { Bir etnik kökene ait olma } \\
\text { ayrıcalık sağlamamalıdır. }\end{array}$ \\
\hline & 8 & 27 & + & ,454 & $\begin{array}{l}\text { Yaşanılan birçok toplumsal } \\
\text { sorunun kökeninde barışın } \\
\text { sağlanamaması yer almaktadır. }\end{array}$ \\
\hline & 9 & 8 & + & ,614 & $\begin{array}{l}\text { Farklı fikirlere sahip olan } \\
\text { insanlara sayg1 duyarım. }\end{array}$ \\
\hline & 10 & 11 & + &, 547 & $\begin{array}{l}\text { Her insan eşit şartlarda } \\
\text { yaşamayı hak eder. }\end{array}$ \\
\hline & 11 & 12 & + & ,627 & $\begin{array}{l}\text { İnsanların dini inançları ne } \\
\text { olursa olsun onlara sayg1 } \\
\text { duyarım. }\end{array}$ \\
\hline & 12 & 2 & + & ,323 & $\begin{array}{l}\text { Kişinin kendi içindeki öfke } \\
\text { bitmeden barış gerçekleşmez. }\end{array}$ \\
\hline & 13 & 24 & - &, 570 & $\begin{array}{l}\text { Dünyada barışın sağlanması } \\
\text { beni ilgilendirmiyor. }\end{array}$ \\
\hline Rarica & 14 & 25 & - &, 521 & $\begin{array}{l}\text { Barışın sağlanmaya çalışılması, } \\
\text { ülkelerin } \\
\text { engelleyebilir. }\end{array}$ \\
\hline Verme & 15 & 26 & - & ,343 & $\begin{array}{l}\text { Barışın gerçekleşmesi kimi } \\
\text { durumlarda bazı grupları } \\
\text { ezebilir. }\end{array}$ \\
\hline & 16 & 32 & - & ,493 & $\begin{array}{l}\text { Barışa yüksek değer veren } \\
\text { insanlar genellikle zayıf ve } \\
\text { korkaktır. }\end{array}$ \\
\hline Kişisel & 17 & 7 & + & ,388 & $\begin{array}{l}\text { Arkadaşlarımla çatışma } \\
\text { yaşadığımda bir an önce sorunu } \\
\text { çözmeye çalışırım. }\end{array}$ \\
\hline $\begin{array}{l}\text { Kişilerarası } \\
\text { Barış }\end{array}$ & 18 & 6 & + & ,436 & $\begin{array}{l}\text { Arkadaşlarım } \quad \text { yanımda } \\
\text { tartışırlarsa onları yatıştırmaya } \\
\text { çalışırım. }\end{array}$ \\
\hline & 19 & 3 & + & ,406 & Barışçıl biriyim. \\
\hline & 20 & 29 & - & ,452 & $\begin{array}{l}\text { Savaş bazen bir çatışmay } \\
\text { çözmenin en iyi yoludur. }\end{array}$ \\
\hline $\begin{array}{l}\text { Savaşıı } \\
\text { Karşısında } \\
\text { Barış }\end{array}$ & 21 & 30 & - & ,339 & $\begin{array}{l}\text { Savaşın bazı durumlarda } \\
\text { kıymetli ve değerli olduğuna } \\
\text { inanıyorum. }\end{array}$ \\
\hline & 22 & 31 & - & ,445 & Barış savaşa hazırlık sürecidir. \\
\hline & 23 & 16 & - & ,319 & $\begin{array}{l}\text { Etnik kökeni benden farklı olan } \\
\text { biriyle evlenmem. }\end{array}$ \\
\hline $\begin{array}{l}\text { Farklılıklara } \\
\text { Açık Olma }\end{array}$ & 24 & 13 & - & ,419 & $\begin{array}{lrr}\text { Kendi inancimdan } & \text { olmayan } \\
\text { biriyle } & \text { arkadaşlık } & \text { etmek } \\
\text { istemem. } & & \end{array}$ \\
\hline & 25 & 18 & - & ,421 & $\begin{array}{l}\text { Kendi kültürel değerlerim } \\
\text { diğerlerinden üstündür. }\end{array}$ \\
\hline
\end{tabular}

Tablo 4'te barış tutum ölçeğinin 25 maddeden oluştuğu ve madde içerikleri görülmektedir. Ayrıca ölçeğin düzeltilmiş madde - toplam korelasyonlarının 0,319 - 0,643 arasında değiştiği görülmektedir. İyi bir ölçekte bu değerin her madde için 0.3 ve üzeri olması gerekmektedir (Field, 2009). Bu araştırmada geliştirilen Barış Tutum Ölçeğinde de bütün maddelerin düzeltilmiş madde - toplam korelasyonlarının 0,3 üzerinde olması, ölçekteki tüm maddelerin, ölçekle uyumlu olduğu ve aynı amaca yönelik çalıştığını gösteren unsurlardan biri 
olmaktadır. Ayrıca tabloda, ölçekteki 15 maddenin olumlu maddeler, 10 maddenin ise olumsuz maddeler olduğu görülmektedir.

Ölçeğin keşfedici faktör analizi süreci tamamlandıktan sonra 1237 sınıf eğitimi programı öğrencisinden yeniden veri toplanmış ve veriler istatistik programına yüklenerek ölçeğin kurama uygunluğunun sınanmasına olanak tanıyan doğrulayıcı faktör analizi işlemi gerçekleştirilmiştir. Diğer bir deyişle, doğrulayıcı faktör analizi ile tahmin edilen ilişki örüntüsü doğrulanmaya çalışılmıştır (DeVellis, 2017). Yapılan işlem sonunda elde edilen Path diyagramı Şekil 4’te verilmiştir.

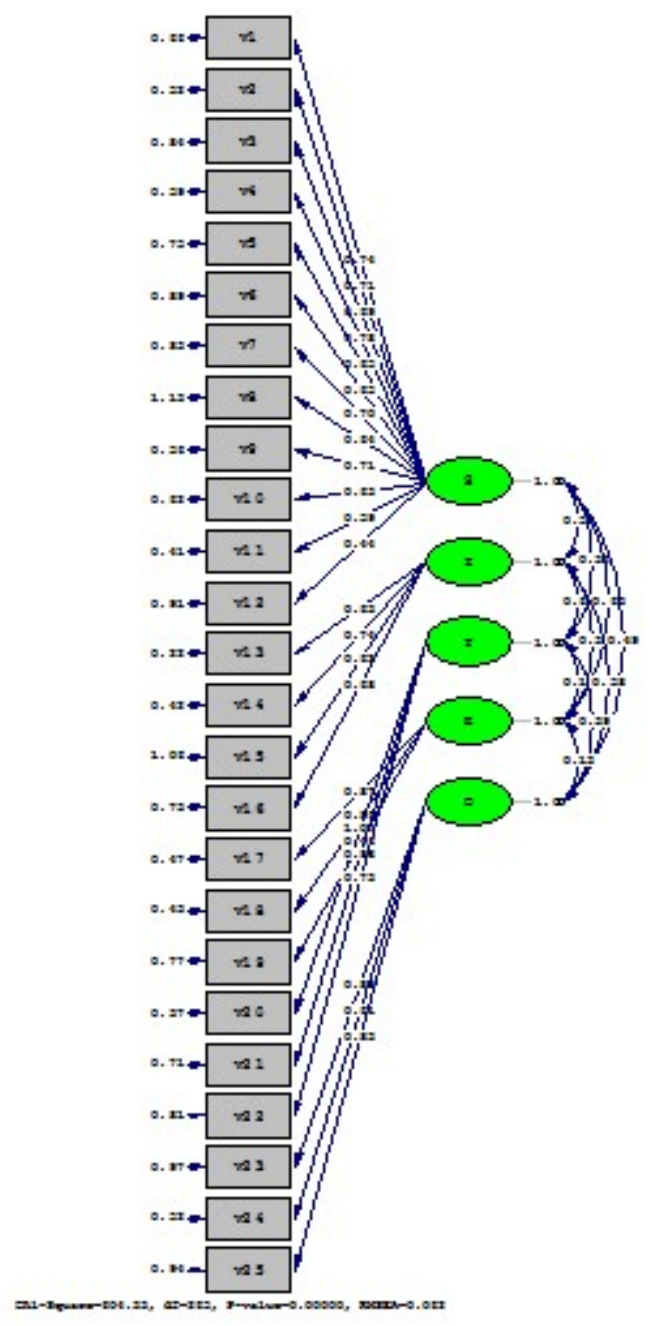

\section{Şekil 4. Barış tutum ölçeğine ilişkin Path diyagramı}

Yapılan analiz sonucunda tüm $t$ değerlerinin .05 düzeyinde anlamlı olduğu görülmüştür. Zaten ilgili şekil incelendiğinde de bu durum görülmektedir. $\mathrm{Bu}$ sonuç, değişkenlerin istatistiksel anlamda belirlenen yapı ile ilişkili olduğunu gösteren parametrelerden yalnız biridir (Hayduk, 1987). Bunu yanı sıra, her maddeye ilişkin faktör yükleri ve hata varyansları incelendiğinde bu değerlerin kabul edilebilir aralıklarda olduğu görülmektedir. Maddelerde en düşük faktör yükü 0,44 'tür. Faktör yükünün 0,3 ve üzerinde olması beklenir (Büyüköztürk, 2012). Dolayısıyla ölçeğe uyumsuz olan herhangi bir madde-faktör ilişkisi olmadığı ifade 
edilebilir. Bu işlemlerin ardından, modelin uyum iyiliği indeksleri incelenmiştir. Modelin uyum değerleri ve Byrne'dan (2011) uyarlanan uyum ölçütleri Tablo 5'te verilmiştir (Yaşlığlu, 2017).

Tablo 5. Modelin Uyum Değerleri ve Uyum Ölçütleri

\begin{tabular}{|c|c|c|}
\hline Uyum Ölçütleri & Kabul Edilebilir Uyum Değerleri & Modelin Uyum Değerleri \\
\hline AGFI & $>0,85$ & 0,84 \\
\hline GFI & $>0,90$ & 0,87 \\
\hline CFI & $>0,92$ & 0,96 \\
\hline NFI & $>0,90$ & 0,93 \\
\hline RMSEA & $<0,07$ & 0,062 \\
\hline$\chi^{2 / s d}$ & $<5$ & $618,71 / 265=2,33$ \\
\hline
\end{tabular}

Tablo 5 incelendiğinde modelin genel olarak kurama iyi ölçüde uyum sağladığ görülmektedir. Yalnız AGFI ve GFI değerinin kabul edilebilir sınırın altında olması dikkat çekmektedir. GFI değeri örneklem büyüdükçe artma eğilimindedir (Bollen, 1990; s. 256-259; akt. Yaşlığlu, 2017). AGFI değeri ise kabul edilebilir düzeye oldukça yakındır. Ayrıca AGFI değerinin çok maddeli ölçeklerde kullanılmaması önerilmektedir (Yaşlığlu, 2017). Dolayısıyla bu değerlerin, istenilen düzeye oldukça yakın olmasından ve tek başına çıkarım yapılması için yeterli olmadığından tüm bulguların Barış Tutum Ölçeğinin faktör yapısını doğrular nitelikte olduğu ifade edilebilir. Bütün bu bilgiler ışığında geliştirilen bu ölçeğin hem uygun geçerlikte hem de yeterli derecede güvenilir olduğu ifade edilebilir.

\section{Tartışma ve Sonuç}

Araştırmanın amacı, sınıf eğitimi anabilim dalı öğrencilerinin barışa yönelik tutumlarını ölçecek geçerlik ve güvenirlikte bir ölçe aracı geliştirilmesidir. Bu amaçtan yola çıkılarak sınıf eğitimi programı öğrencileri için geçerli ve güvenilir bir barış tutum ölçeği geliştirilmiştir. Literatürde çeşitli barış ölçekleri bulunmaktadır (Aktaş, 2012; Eryılmaz, 2014; Lee ve diğ., 2013; Van der Linden ve diğ., 2017). Ancak bu ölçekler içerik ve hedef kitle anlamında bu araştırma amacına uygun bulunmadığından yeni bir ölçek geliştirilmesi hedeflenmiştir. Bu barış tutum ölçeğinin geliştirilmesi sürecinde analizler, barış tutum yapısının beş faktörden oluştuğunu işaret etmiştir. Buna göre, barış tutumu; toplumsal barış, barışa önem verme, kişisel ve kişilerarası barış, savaşın karşısında barış ve farklılıklara açık olma boyutlarından oluşmaktadır. Barış tutum ölçeğinin, bu araştırmada temel alınan UNICEF'in barış eğitimi programında belirtilen, barışa ilişkin belirlenmiş düzey ve gerekçelerle örtüştüğü görülmektedir (Fountain, 1999). UNICEF'in tanımladığ 1 barış kavramının yapısında barışın düzeyleri, insan hakları ve çeşitlilik değişkenleri yer almaktadır. Mevcut çalışmada ortaya çıkan ve barış tutumunun yapısında yer alan toplumsal barış ile barışa önem verme faktörlerinin barışın genel anlamı ile ilişkili faktörler olduğu ifade edilebilir. Diğer bir deyişle, toplumsal barış ve barışa önem verme faktörleri, barış yapısında yer alan üç değişkenden de izler barındırmaktadır. Yine mevcut çalışmada ortaya çıkmış olan faktörlerden biri olan kişisel ve kişilerarası barış faktörü, barış yapısındaki barışın düzeyleri değişkeninde yer alan iki düzeyi birden (kişisel barış ve kişilerarası barış) karşılamaktadır. Eryılmaz'ın (2014) geliştirdiği barışa yönelik tutumlar ölçeğinde de tek faktörde kişisel ve kişiler arası düzeyde barışı ölçen maddelerin bir arada yer aldığı görülmüştür. Dolayısıyla mevcut çalışmanın, Eryılmaz'ın (2014) çalışmasına, bu anlamda uyumlu bir çalışma olduğu ifade edilebilir. Ayrıca bu iki düzeyin bir arada tek faktörde yer alması, çalışma grubundaki bireylerin bu iki düzeyi bir arada görme eğilimleri olduğu 
konusunda bir ipucu vermektedir. Mevcut çalışmada ortaya çıkan savaşın karşısındaki barış faktörü, ağırlıklı olarak barış yapısındaki barışın düzeyleri değişkeninde yer alan uluslararası barış düzeyinin simgesidir. Mevcut çalışmada ortaya çıkan farklılıklara açık olma faktörünün ise ağırlıklı olarak barış yapısında yer alan çeşitlilik değişkenlerini karşıladığı söylenebilir.

Ölçek üzerinde uygulanan keşfedici ve doğrulayıcı faktör analizlerinden elde edilen sonuçlar da bu örtüşmeyi doğrular niteliktedir. Bu anlamda ortaya konulan ölçme aracının, uluslararası barış normlarına da uygun bir araç olduğu ifade edilebilir. Ayrıca, literatürde benzer faktörlerle ortaya konulmuş bir barış tutum ölçeği bulunmadığından, bu bağlamda da özgün bir ölçeğin oluşturulduğu ifade edilebilir (Aktaş, 2012; Eryılmaz, 2014; Van der Linden ve diğ., 2017). Oluşturulan bu ölçeğin farklı anabilim dallarında öğrenim gören öğrencilere göre de uyarlanabileceği önerilmektedir. Barış tutum ölçeğinin alanyazına katkısının olacağı umulmaktadır.

Sınıf Eğitimi Ana Bilim Dalı Öğrencileri için Barış Tutum Ölçeği Gelişstirilmesi başlıklı çalışmanın yazım sürecinde bilimsel, etik ve alıntı kurallarına uyulmuş; toplanan veriler üzerinde herhangi bir tahrifat yapılmamış, karşılaşılacak tüm etik ihlallerde "Pamukkale Üniversitesi Eğitim Fakültesi Dergisi Yayın Kurulunun" hiçbir sorumluluğunun olmadığı, tüm sorumluluğun Sorumlu Yazara ait olduğu ve bu çalışmanın herhangi başka bir akademik yayın ortamına değerlendirme için gönderilmemiş olduğunu taahhüt ederim. 


\section{Kaynakça}

Aktaş, Ö. (2012). Ortaöğretim öğrencilerinin savaş ve barlş konularıyla ilgili bilgilerinin ve tutumlarının çeşitli değişkenler açısından değerlendirilmesi. Ankara: Yayınlanmamış doktora tezi. Gazi Üniversitesi Eğitim Bilimleri Enstitüsü.

Allport, G. W. (1979). The nature of prejudice: 25th Anniversary Edition. Newyork: Ingram publisher services US.

Ayaz, M. F. (2016). Çokkültürlülük algı ölçeği: Geçerlik ve güvenirlik çalışması. Elektronik Sosyal Bilimler Dergisi, 15(57), 463-471.

Banks, J. A. (2013). Çokkültürlü eğitime giriş. (H. Aydın, Çev.) Ankara: Anı Yayıncılık.

Bayraktar, B. (2012). Bir barış süreci örneği olarak Oslo. İstanbul: Yayınlanmamış doktora tezi. Marmara Üniversitesi Ortadoğu Araştırmaları Enstitürü.

Büyüköztürk, Ş. (2012). Sosyal bilimler için veri analizi el kitabı. Ankara: Pegem Yayıncılı.

Çalışkan, H., ve Sağlam, H. İ. (2012). Hoşgörü eğilim ölçeğinin geliştirilmesi ve ilköğretim öğrencilerinin hoşgörü eğilimlerinin çeşitli değişkenler açısından incelenmesi. Kuram ve Uygulamada Eğitim Bilimleri, 12(2), 1431-1446.

Çoban, B. (2008). Toplumsal barış, sivil toplum kuruluşları ve iletişim: barış, öteki, önyargı ve çatışma üzerine. Global Peace, 77-85.

Çokluk, Ö., Şekercioğlu, G., ve Büyüköztürk, Ş. (2012). Sosyal bilimler için çok değişkenli istatistik: SPSS ve Lisrel uygulamaları. Ankara: Pegem Akademi Yayıncılık.

Damgacı, F., ve Aydın, H. (2013). Akademisyenlerin çokkültürlü eğitime ilişkin tutumları. Elektronik Sosyal Bilimler Dergisi, 12(45), 325-341.

DeVellis, R. F. (2017). Ölçek geliştirme: Kuram ve uygulamalar (3. b.). (T. Totan, Çev.) Ankara: Nobel Yayıncilik.

Eryılmaz, A. (2014). Relationship of peace attitudes with personality traits, gender and age groups. Düşünen Adam Dergisi, 27(2), 138-146.

Fabrigar, L. R., Wegener, D. T., MacCallum, R. C., \& Strahan, E. J. (1999). Evaluating the use of exploratory factor analysis in psychological research. Psychological Methods, 4(3), 272-299.

Field, A. (2009). Discovering statistics using SPSS. London: SAGE Publications.

Fountain, S. (1999). Peace education in UNICEF. New York. PD-ED-99/003: UNICEF Staff Working Papers. Working Paper Education Section Programme Division UNICEF.

Fraenkel, J. R., \& Wallen, N. E. (2009). How to design and evaluate research in education. New York: The McGraw - Hill.

Galtung, J. (1985). Twenty-five years of peace research: Ten challenges and some responses. Journal of Peace Research, 22(2), 141-158.

Hayduk, L. A. (1987). Structural equation modeling with LISREL: Essentials and advances. Maryland: Jhu Press.

Karaman-Kepenekçi, Y. (2010). Üniversite öğrencilerinin ulusal ve uluslararası barışa ilişkin görüşleri, Ankara Üniversitesi Ĕ̈itim Bilimleri Fakültesi Dergisi, 43(2), 27-49. 
Kartal, S. (2018, 05 26). Son öğretmen yetiştirme programları üzerine -ìki sekiz bir dokuz, üç yirmi bir otuz-. 05 30, 2018 tarihinde Sadik Kartal Blog: http://sadikartal.blogspot.com/2018/05/sonogretmen-yetistirme-programlari.html adresinden alındı

Kerem, E. A., ve Kamaraj, I. (2006). Erken çocukluk dönemi 'barış' değerine evrensel bir bakış. Atatürk Üniversitesi Kazım Karabekir Eğitim Fakültesi Dergisi, (13), 81-92.

Kılcan, B. (2018). Bireysel barışa yönelik tutum ölçeğinin geliştirilmesi: Geçerlik ve güvenirlik çalışmaları/Development of a scale measuring attitudes towards individual peace: A validity and reliability study. Journal of History Culture and Art Research, 7(1), 398-413.

Lee, Y. C., Lin, Y. C., Huang, C. L., \& Fredrickson, B. L. (2013). The construct and measurement of peace of mind. Journal of Happiness studies, 14(2), 571-590.

Munroe, A., \& Pearson, C. (2006). The Munroe multicultural attitude scale questionnaire: A new instrument for multicultural studies. Educational and Psychological Measurement, 66(5), 819834.

Obidike, N. D., Bosah, I., \& Olibie, E. (2015). Teaching peace concept to children. International Journal of Multidisciplinary Research and Development, 2(6), 24-26.

Özkan, S. (2015). İnsan haklarının tarihsel gelişimi ve kuşak sınıflandırması. Akdeniz Üniversitesi Hukuk Fakültesi Dergisi, 5(1), 111-126.

Pakyürek, G. (2013). The philosophical and historical bases of interdisciplinary approach in cognitive science. Journal of Faculty of Letters, 30(2), 161-172.

Park, H. S., Dailey, R., \& Lemus, D. (2002). The use of exploratory factor analysis and principal components analysis in communication research. Human Communication Research, 28(4), $562-567$.

Polat, S. (2012). Okul müdürlerinin çokkültürlülüğe ilişkin tutumları. Hacettepe Üniversitesi Eğitim Fakültesi Dergisi, 42, 334-343.

Purde, K. (2013). Savaşın yazımı: 16. Yüzyıl Osmanlı kroniklerinde savaş olgusuna bakış (Uzun savaşlar örneğinde). İstanbul: Yayınlanmamış Yüksek Lisans Tezi. İstanbul Üniversitesi Sosyal Bilimler Enstitüsü.

Tavşancıl, E. (2002). Tutumların ölçülmesi ve SPSS ile veri analizi. Ankara: Nobel Yayıncılık.

TDK. (2016). Türk Dil Кигити. 09 20, 2016 tarihinde http://www.tdk.gov.tr/index.php?option=com_gts\&arama=gts\&guid=TDK.GTS.541dbc03c3c8 10.36615389 adresinden alınd 1

Tezbaşaran, A. A. (2008). Likert tipi ölçek hazırlama kılavuzu. 10 27, 2017 tarihinde Academia: https://www.academia.edu/1288035/Likert_Tipi_\%C3\%961\%C3\%A7ek_Haz\%C4\%B1rlama_ $\mathrm{K} \% \mathrm{C} 4 \% \mathrm{~B} 1$ lavuzu adresinden alınd 1

Tunçay, M. (2016). Batı'da siyasi düşünceler tarihi 2/ Yeni Çağ. İstanbul: İstanbul Bilgi Üniversitesi Yayınları.

UNESCO. (2002). UNESCO Prize for peace education. 02 10, 2016 tarihinde http://unesdoc.unesco.org/images/0012/001290/129085e.pdf adresinden alınd1

Van der Linden, N., Leys, C., Klein, O., \& Bouchat, P. (2017). Are attitudes toward peace and war the two sides of the same coin? Evidence to the contrary from a French validation of the Attitudes Toward Peace and War Scale. PLOS ONE, 12(9). 
Vasak, K. (1977). 30-Year struggle-sustained efforts to give force of law to Unıversal-Declaratıon-ofHuman-Rights. UNESCO Courier, 28(10).

Yaşlıoğlu, M. M. (2017). Sosyal bilimlerde faktör analizi ve geçerlilik: keşfedici ve doğrulayıcı faktör analizlerinin kullanılması. Istanbul University Journal of the School of Business, 46, 74-85.

Zöller, M. (2012). A Comparison between Principal Component Analysis and Factor Analysis. (s. 1-4). University of Applied Sciences Wurzburg-Schweinfurt. 16.07.2012. 10 10, 2019 tarihinde http://citeseerx.ist.psu.edu/viewdoc/download?doi=10.1.1.251.2834\&rep=rep1\&type=pdf adresinden alınd 1 


\section{Extended Abstract}

\section{Introduction}

Since ancient times, humans have been in a race for superiority. Millions of people have been negatively impacted by wars, one of the consequences of the race for superiority (Purde, 2013). As wars have proliferated, the concept of peace has become more and more discussed by researchers. Peace brings to mind the definition of warlessness. However, this definition is not enough to explain the concept of peace. UNESCO (2002) defines peace as a phenomenon that is based on tolerance and solidarity and does not include gender discrimination, which creates environments where individuals can express themselves easily and in which the democratic participation of individuals is supported, and the labor given to economic and social development and respect for human rights are increased. Thus, it can be said that peace is a process that embraces tolerance, respects differences, and is based on solidarity and human rights. Attitude is the tendency to react to various concepts or situations (Tezbasaran, 2008). Primary school teachers are needed to construct a society of individuals with a high attitude towards peace. For this reason, the attitudes future primary school teachers have towards peace should be understood. No suitable measurement tool for measuring the attitudes of primary school teachers or students of primary education programs was found in the literature. Therefore, the aim of the present study was to develop a peace attitude scale that can be used to understand the peace attitude levels of primary education program students.

\section{Method}

The present study is basic research and its main research question is: "What kind of a measurement tool can be used to measure the attitudes primary education program students have towards peace?". The research universe was composed of students of the primary education departments of faculties of education in Turkey. The scale was applied to the primary education departments of various universities. Firstly, based on relevant research, the peace attitude was defined within a framework. Then, the feelings and thoughts of 81 teachers / primary education program students regarding peace were acquired. Similar scales in the literature were examined and items suitable for the purpose of the present study were abstracted from these scales. A total of 24 items from these scales were found to meet various dimensions of the peace attitude but were inadequate to meet the determined sub-dimensions. A further nine more items were created by the researcher related to the missing sub-dimensions. Expert opinion was taken for the scale, which was applied to the participants.

\section{Results and Discussion}

Cronbach's alpha coefficient was calculated for reliability analysis and exploratory and confirmatory factor analyses were applied for validity. Firstly, exploratory factor analysis was performed on the collected data. Then, the data, to which principal axes factoring was applied, was examined using the Varimax rotation method. A total of eight items with low item factor load were excluded from the scale. As a result, a scale consisting of five factors and 25 items was achieved. The factors were named according to the contents of the items. The first factor was named as "social peace", the second as "giving importance to peace", the third as "personal and interpersonal peace", the fourth as "peace versus war" and the fifth as "being open to differences". While developing the scale, it was thought that the levels of peace (personal, 
interpersonal, intergroup, national and international) would determine the factors. However, when the factors that emerged as a result of the analyses were examined, it was seen that the structure better matched the content of the peace attitude of UNICEF, which was one of the main resources of the present study. The five factors of the developed scale explained $47.02 \%$ of the total variance. Cronbach's Alpha, the reliability coefficient for the scale, was calculated as 0.89 . Findings obtained from the confirmatory factor analysis confirmed the factor structure of the developed peace attitude scale. In light of all this information, it can be stated that the developed scale is both reliable and sufficiently valid.

Various peace scales were found in the literature (Aktas, 2012; Eryilmaz, 2014; Lee et al., 2013; Van der Linden et al., 2017). However, as these scales were deemed not suitable for the purpose of the present study in terms of content and target audience, a new scale was aimed to be developed. In the process of developing this peace attitude scale, analyses indicated that the peace attitude structure should consist of five factors: (1) social peace, (2) giving importance to peace, (3) personal and interpersonal peace, (4) peace versus war and (5) being open to differences. It was seen that the peace attitude scale of the present study coincided with the determined levels and reasons for peace stated in UNICEF's peace education program (Fountain, 1999). The results obtained from the exploratory and confirmatory factor analyses applied to the scale confirmed this overlap. In this sense, it can be stated that the measurement tool put forward by this study is a tool that is also suitable for international peace norms. In addition, since there is no peace attitude scale in the literature with similar factors, it can be stated that an original scale was created (Aktas, 2012; Eryilmaz, 2014; Van der Linden et al., 2017). The explanation of the peace attitude with this structure was supported by the relevant literature review. This scale can be adapted to students studying in various different departments. It is hoped that the developed peace attitude scale will contribute to the literature. 